\title{
KMT2E wt Allele
}

National Cancer Institute

\section{Source}

National Cancer Institute. KMT2E wt Allele. NCI Thesaurus. Code C93095.

Human KMT2E wild-type allele is located in the vicinity of 7q22.1 and is approximately $100 \mathrm{~kb}$ in length. This allele, which encodes histone-lysine $\mathrm{N}$-methyltransferase $2 \mathrm{E}$ protein, plays a role in the mediation of histone methylation and the regulation of both transcription and the cell cycle. 